\title{
Basic Factors Influencing Participative Readiness of Future Teachers: Social Activity Through Cooperation
}

\author{
Viktoriya Valerievna Danilova
}

Master of Pedagogy and Psychology, Senior Teacher of English, Department of Foreign Languages Kostanay State Pedagogical Institute; E-mail: vukvuk85@mail.ru

Nataliya Viktorovna Uvarina

Doctor of Pedagogical Sciences, Professor, Department of Teacher Training for Professional Education and Specialized Methods,Chelyabinsk State Pedagogical University; E-mail: nuvarina@yandex.ru

Tanzilya Kamilevna Sagitdinova

Master of Foreign Philology, Teacher, Department of Germanic Philology North Kazakhstan State University Named After M.Kozybayev; E-mail: a_tanzilya@mail.ru

Assel Saghindykovna Amrenova

Candidate of Philological Sciences, Associate Professor, Department of Germanic Philology North Kazakhstan State University Named After M.Kozybayev; E-mail: assel.s.a14@gmail.com

Alyona Vyacheslavovna Starkova

Master of Humanity Sciences, Teacher, Department of Germanic Philology North Kazakhstan State University Named After M.Kozybayev; E-mail: elvenbride@inbox.ru

\author{
Doi:10.5901/mjss.2015.v6n6s1p48
}

\section{Abstract}

The given article is devoted to specific training of future teachers based on participation and involvement into the social life inside and outside the higher educational institution (HEI). The goal of the article is to show the influence of external and internal factors on the process of forming participative readiness of future teachers for social activity. Participation is presented as a way of organization of collaboration and sustaining education in the system of 'teacher-student-student' mode. The article deals with the structure of the external and internal environment of HEl including the "shift" of professional qualities of future teachers. Cooperation of students as future teachers is viewed through three various aspects: tandem method of organization of social activity of students, the use of ICT as a tool for developing social activity of future teachers and collective management of students applied to the educational process in HEl. The authors present data proving the effectiveness of each aspect against its complex use applied to the process of forming the participative readiness of future teachers. The results of comparison of the influence of each factor are shown as less effective related to their complex functioning.

Keywords: participation, internal and external environment, ICT, tandem method, co-management

\section{Introduction}

As Ekanem and Ekefre (Ekanem and Ekefre, 2013) state "... education remains the best and basic means of transmitting and perpetuating culture for general development and technological advancement". Education, development and culture cannot be separated from the human viewed basically as a transformer of social connections. Furthermore, the student of any teacher training institutions must be ready to organise various and vivid social activities inside and outside the classroom. Consequently, having been exposed to factors influencing the forming of such a readiness, the student has to be an active participant of a social intercourse.

Participation as a notion has derived from the sphere of management (Keith Davis «The Case for Participative Management», Davis, 1963) and viewed as a system of taking decision (Lowin, 1968, Neuschel, 1969) regardless the 
human factors or the personality-oriented participative management (Lawrence, Steinmetz, Greenidge, 1970, etc.) that gave the way to the theory of leadership based on participation (Koprowski, 1967), (Gary, 1971) and others).

The turning point in the theory of particiation is connected with the semantic penetration of this notion into the theory of education - the article of Wolfgang Beywl "A participative future: The conditions of living in the future and their consequences for education" (Beywl, 1978).

Participation in education has been scrutinised from the view point of "involving", "taking part", "engaging", "attracting". In pedagogical sciences the term "participation" is the attribute for "vast attraction of the subjects of interaction to the realisation of the programmes of socially-valued activity based on cooperation" (Gavrikov, Orlov, Pevzner, Sheraizina, 2004) or as the method of forming pedagogical collective having impact on the process of peer responcibility and collaboration.

We consider participation viewed by E.B. Bystray as the way of organising students when solving problems including "active involvement of each of them", coinvolvement and immersiveness of all participants (Bystray, 2003). University student perspectives on classroom participation by Leslie, K.J. (Leslie, 2012), the influence of multicultural context in the classroom when dealing with participation from the side of the teacher (Kano, 2014: Fatima, 2009) made us consider the choice of factors having greater impact on the forming of participative readiness of future teachers for social work both as input and output in HEls.

\section{Participative Readiness for Social Work - Context and Environment}

Social work cannot be parted from participation. Students are to be ready to handle with difficulties in reality that can occur while their training in HEls (including factors from inside and outside of the educational process). This article presents the attempt of authors to illustrate three basic factors influencing the participative readiness of future teachers for social work based on cooperation. Thus, we include the following aspects:

- Tandem method of organization of social activity of students;

- The use of ICT as a tool for developing social activity of future teachers;

- Collective management of students applied to the educational process in HEI.

\section{The Problem}

This study seeks to assist future teachers of HEls for better social activity involvement within the framework of and out of institution. The factors that influence the readiness of future teachers for social activity involvement must represent internal and external aspects of pedagogical phenomenon.

\section{Research Hypothesis}

The following hypothesis is raised for this study: There will be a significant relationship between external and internal factors of the educational institution that results in the "shift" of professional qualities of students applied to their social activity.

\section{Methodology}

The choice of methodology stated below is based on the following aspects:

1. peculiarities of participative readiness of future teachers for social activity as two-side process;

2. flexibility of social environment in the system 'teacher-student-pupil';

3. necessity of the focus on interrelation of external and internal factors of educational institution when forming participative readiness.

\subsection{Research Objectives and Experimental Course:}

The following objectives have been put forward:

1. To analyse the relations between external and internal factors of educational institution applied to forming social readiness of future teachers.

2. To examine the interdependence of tandem method, ICT and the collective management of students applied to the educational process in $\mathrm{HEI}$. 
The special Programme for the course "Theory and Methods of Upbringing work" was elaborated for this experimental part of the research.

\subsection{External factors influencing participative readiness of future teachers applied to social activity.}

External factors include the influence of social environment on the participative readiness of future teachers. Consequently, the following layers of the stated environment are presented below in the interconnection with internal structure of the HEls (Pic.1):

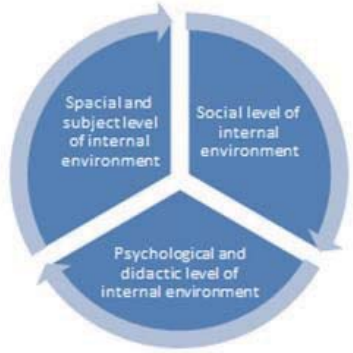

Intemal environment of the HEI (Yasvin, 2001)

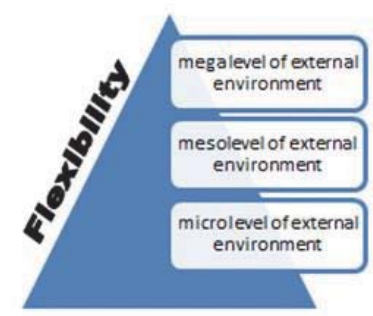

Flexibility of extemal environment (Leontieva, 2007)

Picture 1. Internal and External environment of HEI

\section{Discussion: Challenges and Directions}

Having identified three levels of environment of $\mathrm{HEI}$, the following aspects or conditions for raising effectiveness of forming participative readiness of future teachers for social activity can be put forward:

1. Tandem method of organization of social activity of students (social level of the internal environment and microlevel of external environment penetrating into it);

2. The use of ICT as a tool for developing social activity of future teachers (psychological and didactic, special and subject levels of the internal environment and micro- and mesolevels of external environment penetrating into it);

3. Collective management of students applied to the educational process in HEI (social level of the internal environment and meso- and megalevels of external environment penetrating into it).

\subsection{Tandem method of organization of social activity of students}

Tandem method is based on "student-student" organised social activities. Actually, this method has been widely used in linguistic education or for FLTL (Foreign Language teaching and Learning). For example, the vast number of work are dedicated to various forms of LTL: web-based tandem by Appel, M.C. and Mullen, T. (Appel \& Mullen, 2000); peer assessment in Tandem language learning by Morley, J. (Morley, 2006); the connection of learner autonomy to Tandem method in language learning by Little, D. (Little, 2003); reciprocity of Tandem in FLTL by N. Fernández-Quesada (Fernández-Quesada, 2015) and etc.

The main characteristics of Tandem as a method irrespective its shpere of implementation are the following:

- Dual character and interdependence,

- Reciprocity of influence,

- Exchange and mobility of communication.

Within the framework of our experimental course "Theory and Methods of Upbringing work" we advised students to work in pairs for further planning, organising and analysing social activities (debates, role-plays, talk-shows).

Pairs of students (Student 1 - Student 2) were supposed to develop the plan for debates/role-plays or talk shows, including roles, charts for assessment and organise this social activity at class (for their peers). Basically, 13 various activities have been organised by students, the topics for such activities were connected with school life and social 
problems (i.e. topic for the debate "Upbringing: who is blame - parents or school?", role play "The lesson of English how to manage the class", talk-show with a famous teacher of Kostanay/Petropavlovsk, etc.).

The results of effectiveness of forming participative readiness for social activity when using Tandem method in the EG - experimental group - are shown below (in comparison with the group that did not undergo any influence - CG control group) (see Table 1):

Table 1 - Results of the use of Tandem method in experimental and control groups:

\begin{tabular}{|c|c|c|c|}
\hline Groups & Low level of readiness, per cent & Medium level of readiness, per cent & High / Sufficient level of readiness, per cent \\
\hline CG & 68 & 30 & 2 \\
\hline EG & 49 & 32 & 19 \\
\hline
\end{tabular}

Judging by the results, the level of effectiveness has been greatly raised in experimental group that underwent the influence of Tandem method applied to forming readiness of future teachers for social activity.

\subsection{The use of ICT as a tool for developing social activity of future teachers}

The use of ICT in all spheres of study is inevitable nowadays. The role of ICT has been scrutinised in teacher education by Avril Loveless, Jeremy Burton, Keith Turvey (Loveless, Burton, Turvey, 2006), Alev, N. (Alev, 2003), etc.

The connection between the social readiness of future teachers and the use of ICT has been partly revealed by A. Contarello, M. Sarrica via connection of Internet representation to social well-being (Contarello, Sarrica, 2007); Funda Erdogdua, Erkan Erdogdu via correlation between ICT and student background and school (Erdogdua, Erdogdu, 2015), etc. Researches in this field have demonstrated positive and negative influence of ICT on social aspect of student's personality.

In our research we used the following ICT to raise the effectiveness of forming participative readiness of future teachers for social activity:

1. Blogging (or electronic open diary / three-part diary);

2. Webinars (during active school practice of students);

3. Rubrics for assessment of social work organised.

Consequently, students have been writing their blogs on the chosen social topic for 7 weeks (the duration of the school practice), adding commentaries to other students' blogs. This service developed the ability to see social problems in everyday school life, respond to them, analyse and forsee the possible outcome of pedagogical communication.

Webinars have been organized by students twice during their school practice to emerge the experience of other students gained in the mid and at the end of this practice. Webinars were effective to represent differences in style of organizing, performing social activities by students.

Assessment and evaluation of social activities were made by generating online rubrics (peer generating or use of ready-made ones) because rubrics help to make "active Learning Practices for Schools" (Andrade, 1999, 2000).

Let us consider the results of the use of ICT for raising the effectiveness of forming participative readiness for social activity in the EG in comparison with the CG (see Table 2):

Table 2 - Results of the use of ICT in EG and CG:

\begin{tabular}{|c|c|c|c|}
\hline Groups & Low level of readiness, per cent & Medium level of readiness, per cent & High / Sufficient level of readiness, per cent \\
\hline CG & 60 & 38 & 2 \\
\hline EG & 38 & 35 & 28 \\
\hline
\end{tabular}

As we can observe, the use of ICT has a positive effect in EG over CG in terms of increasing the percentage of students having sufficient level of participative readiness for social activity.

Below we present the combine use of the first and second conditions in EG versus CG. The results of effectiveness of forming participative readiness for social activity in the EG when using ICT and Tandem method are shown below (in comparison with the group that did not undergo any influence - CG) (see Table 3): 
Table 3 - Results of the use of ICT combined with Tandem method in EG and CG:

\begin{tabular}{|c|c|c|c|}
\hline Groups & Low level of readiness, per cent & Medium level of readiness, per cent & High / Sufficient level of readiness, per cent \\
\hline CG & 60 & 38 & 2 \\
\hline EG & 39 & 30 & 31 \\
\hline
\end{tabular}

We observe the following changes in EG - the decrease of students on the low level of participative readiness (in 10\%), increase in the number of students on the high level (to $31 \%$ in comparison with 19\%) that proves the effectiveness of combined use of the stated above conditions.

\subsection{Collective management of students applied to the educational process in HEI}

Cooperative management in education is a "part of the learning management for creating and developing student to be hands-on graduates" (Sermsuk, 2013). This condition is aimed at raising reflective and organasing professional qualities of future teachers. What do we mean by 'collective management'?

Collective management or 'co-management' is the type of collaboration based on peer responsibility of students inside educational institution in the sphere of social work.

This notion has various interpretations:

1. From the view point of social philosophy it is "the way of positive interaction, coordination, cooperation of centered concentration of spiritual morality of elements of open unbalanced cluster systems on the base of reverse non-linear formative connections aimed at mastering the practical means of cognition of new spiritual and moral paradigm of perpetual self-growth of personality" (Korsakova, 2003).

2. From the view point of management in education: «qualitative level of management which is characterized by wide involvement of co-workers, pupils and students by the leader into the process of taking decisions" (Kanaev, 2005).

3. From the view point of sociology of management: "the process that includes several stages of development of interaction: realisation of the meaning and purposes of collective managing activity, correction used to enriching this process in possible changing in activity and separate acts" (Prokazina, 2003) and etc.

In our research we imply the following definition of collective management of students applied to the educational process in HEl: 'co-management' is the process of interaction of students when they plan, organize and diagnose the effectiveness of social activity on the base of collective taking decisions, coordination and cooperation.

The problems of co-management in education have been studied by Kanaev, R.Kh. (Kanaev, 2005) through the aspect of social initiative as a factor of co-management); Tamarskaya, N.V. (Tamarskaya, 2003) viewing the level of comanagement as the highest level of managing culture of the teacher; Tokareva, L.A. presenting co-management as a condition for modernisation (Tokareva, 2001); Utorov, O.R. studying self-realisation of the teen in the condition of comanagement (Utorov, 2008); Muronga, M.M. (Muronga, 2011) presenting co-management through connection between participation in the management and decision-making and other.

In our research co-management refers to active position of students when taking managing decisions being included into the structural levels of heigher educational institution. So, the student is found in between of the vertical and horizontal levels of the institution, Having analysed the theory of co-management at school by S.S. Slobodyanik, we built the analogy for this process applied to HEls (Slobodyanik, 2000). Basic principle for co-management is the principle of forming teams and managing innovations. Let us consider the place of the student taking this principle into account when viewing him functioning on the levels of HEls (with the focus on social work in HEIs). There are two types of structures of HEls applied to social work - permanent and temporary:

Permanent structures:

1) Department for upbringing work and extracurricular activities (vice-rector of upbringing and extracurricular work);

2) Faculties and Chairs (Deputy of the Dean for upbringing and extracurricular work);

3) Autonomous bodies (Committee of Youth Acts - CYA, students professional organization, alliance of students, etc.);

4) Advisors institutions (participation in the Advisors' Council);

5) Monitors meetings (participation of the active part of the groups in monitors meetings);

6) Clubs and sections.

Temporary structures (created for short-term goals): 
1) Informative and social groups, meetings;

2) Labour teams;

3) Other temporary collectives.

Involvement of future teachers into co-management is directed to active interaction of official bodies and students themselves (having the official status of being involved or not) in all structural levels of higher educational institutions vertically and horizontally functioning (linear and functional type of interaction). As an example, we can put forward the process of taking decisions while meetings of Advisors' Council, Council of the Faculty, monitors meetings, Committee of Youth Acts, clubs, sections and other extracurricular forms of social activity of future teachers.

Direct influence of students on the process of decision-making is felt by the inclusion of future teachers into the structural official bodies of the institution as their members, active participants and responsible figures (as a member of Council of the Faculty, Advisors' Council, active bodies of Committee of Youth Acts and other). Indirect influence of students on the process of decision-making is realized by the interaction inside the group with its active bodies, temporary groups, etc.

Co-management of future teachers in the aspect of upbringing activity of the educational institution has the forms of functioning as the confirmed statute, work plan, protocols, etc. that factually characterizes the direct impact on the aspect of development of the reflective skills according to gained results related to the process of such an activity itself.

Reflective and operational character of this condition demonstrates forming of skills of independent (without any assistance of the teacher) and mutual (in the system of 'student-student', 'student - administrative body', 'student students', etc.) planning, organizing, diagnosing of upbringing activity; skills of stimulating character (involving other students in the process of co-management); communicative skills (both in written and oral representations); skills of team-forming (sharing roles between participants of the activity, their responsibilities based on psychological peculiarities and the principle of complementarity in upbringing activity); correction making skills (finding necessary combination of upbringing effect in case of deviation, skills of step-by-step reflection of upbringing actions, etc.); constructive skills (abilities to choose the content of social work and upbringing activity in accordance with the purposes of the departments; skills of choosing compositional forms of social work including methods and means of upbringing activity, etc.) and other.

Let us present the effectiveness of the use of co-management of students applied to the educational process in HEI as the third condition in our research used separetely in the EG (see Table 4):

Table 4 - Results of the use of collective management in EG and CG:

\begin{tabular}{|c|c|c|c|}
\hline Groups & Low level of readiness, per cent & Medium level of readiness, per cent & High / Sufficient level of readiness, per cent \\
\hline CG & 60 & 38 & 2 \\
\hline EG & 31 & 39 & 30 \\
\hline
\end{tabular}

In any case, we observe the positive dynamics in decreasing the number of students having low level of participative readiness for social work and increasing of those having medium and high level of the stated above readiness.

The results of the use of collective management, ICT and Tandem method combined in EG are presented below (see Table 5):

Table 5 - Results of the use of collective management, ICT combined with Tandem method in EG and CG:

\begin{tabular}{|c|c|c|c|}
\hline Groups & Low level of readiness, per cent & Medium level of readiness, per cent & High / Sufficient level of readiness, per cent \\
\hline CG & 60 & 38 & 2 \\
\hline EG & 22 & 43 & 35 \\
\hline
\end{tabular}

Judging by the results presented above, we can conclude that involvement of future teachers into social work by means of external and internal aspects of HEls in the integrated way bring visible results. These results are reflected even in the shift of professional qualities being based on human intercourse and flexibility of relations.

The influence of each condition taken separately is also inevitable, but better results are gained when all three conditions are used together.

\section{Conclusion}

To sum up, it is necessary to emphasize that the complex use of conditions stated above (Tandem method of 
organization of social activity of students; the use of ICT as a tool for developing social activity of future teachers; collective management of students applied to the educational process in HEI) have positive impact on the process of forming participative readiness of future teachers for social work. Presenting external and internal factors of forming such a readiness, these conditions differently influence on the shift of professional qualities. The influence is of these types: the use of Tandem method has the great impact on the quality of flexibility (students must be ready for psychological peculiarities of the others); ICT develops communication of students in written and oral forms; co-management implies the shift to managing of students developing such qualities as responsibility and the power of observation, skills of teamforming and mutual dependence, openness and parity of interaction. These conditions illustrate unequal influence of internal and external environment of HEls when forming participative readiness of future teachers for social activity.

The overall conclusion can be stated as follows: the better choice of aspects of influence is, the more effective the process of forming participative readiness of future teachers can take place. This research has perspectives in the field of analyzing other factors influencing the studied process: the role of personality traits of character, motivation, interests, beliefs and etc.

\section{Acknowledgement}

We are grateful to the Dean of the Faculty of Foreign Languages, KSPI, candidate of philosophical sciences Doroshok E.L. and the Chairwoman of Foreign Languages Department, KSPI, candidate of pedagogical sciences Kudritskaya M.I. for assistance in carrying out the experiment.

\section{References}

Alev, N. (2003). Integrating Information and Communications Technology (ICT) into Pre-service Science Teacher Education: The Challenges of Change in a Turkish Faculty of Education. Unpublished EdD Thesis, University of Leicester, School of Education, UK.

Andrade, G.H. (1999). Understanding Rubrics. Active Learning Practices for Schools, Harvard University Graduate School of Education and Project Zero. Available at URL: http://www.learner.org/workshops/socialstudies/UnderstandingRubrics.pdf.

Andrade, G.H. (2000). Using rubrics to promote thinking and learning. Educational Leadership, 57(5). 2000. 13-18.

Appel, M.C. \& Mullen, T. (2000). Pedagogical considerations for a web-based tandem language learning environment. Computers \& Education, 34, pp. 291-308.

Beywl, W. (1978). A participative future: The conditions of living in the future and their consequences for education, organized by the Gesellschaft für Zukunftsfragen, West Berlin. - Futures. 11 (2). 170-171.

Bystray, E.B. (2003). Crosscultural and participative approach as a theoretical and methodological strategy of forming crosscultural pedagogical competence. Bulletin of OSU, pp. 78-83.

Contarello, A., Sarrica, M. (2007). ICTs, social thinking and subjective well-being - The internet and its representations in everyday life. Computers in Human Behavior, Special Issue: Internet and Well-Being in Honor of the Memory of Michael Argyle. 23 (2). 10161032.

Davis, K. (1963). The case for participative management. Original Research Article. Business Horizons, 6 (3). 55-60.

Ekanem, S.A., Ekefre, E.N. (2013). Ethics and Professionalism in Education as Tools for Social Reconstruction and Development, Mediterranean Journal of Social Sciences, 4 (14), 15-21.

Erdogdua F., Erdogdu E. (2015). The impact of access to ICT, student background and school/home environment on academic success of students in Turkey: An international comparative analysis. Computers \& Education. Vol. 82. 26-49.

Faheema, A. (2009). Teacher preparedness in dealing with learners social problem. Cape Peninsula University of Technology. Available at URL: http://digitalknowledge.cput.ac.za/xmlui/handle/11189/341

Fernández-Quesada, N. (2015). Just the Two of us? The "¿Qué tal?" E-tandem Project for Translation Students. Procedia - Social and Behavioral Sciences, Vol. 173. 31-36.

Gavrikov, A.L. (2004). Strategic management of HEl: study manual, A.L. Gavrikov et al. Moscow: New Book, 400 p.

Kanaev, P.Kh. (2005). Social initiative as a factor of co-management in educational institution: PhD dissertation, Makhachkala, 178 p.

Kano, J.V. (2014). Participation in the Classroom: Teachers' Perceptions of the Participation of Multicultural Students in the Classroom. Utah Valley University. Available at URL: http://contentdm.uvu.edu:81/u?/UVUTheses,633

Koprowski, E.J. (1967). Toward innovative leadership. Business Horizons. 10 (4). 79-88.

Korsakova, T.A. (2003). Philosophical and praxiological bases for co-management of human development: PhD dissertation. Yakutsk. $144 \mathrm{p}$.

Lawrence, L., Steinmetz, Ch., Greenidge, D. (1970). Realities that shape managerial style: Participative philosophy won't always work. Business Horizons, 13 (5). 23-32.

Leontieva, O.L. (2007). Internal environment oft he HEl: mechanisms of transformation of alternations of external factors into ideological innovations. Modern scientific technologies, 12. 107-110.

Leslie, K.J. (2012). Exploring university student perspectives on classroom participation. Degree: MS, Communication, University of 
Utah.

Little, D. (2003). Tandem language learning and learner autonomy. In T. Lewis \& L. Walker (Eds), Autonomous language learning in tandem (pp. 37-44). Sheffield: Academy Electronic Publications.

Loveless, A. Burton, J. Turvey, K. (2006). Developing conceptual frameworks for creativity, ICT and teacher education, Thinking Skills and Creativity, Vol.1, Issue 1. 3-13.

Lowin, A. (1968). Participative decision making: A model, literature critique, and prescriptions for research. Organizational Behavior and Human Performance. 3 (1). 68-106.

Morley, J. (2006). Incorporating peer assessment into tandem learning. Language Learning Journal, 33 (1), $53-8$.

Muronga, M.M. (2011). The participation of teachers in the management and decision-making of three schools in the Kavango region of Namibia: a case study. Rhodes University. Available at URL: http://eprints.ru.ac.za/3088/.

Neuschel, R.P. (1969). Presidential style: Updated versions: Autocrat yields to participative management. Business Horizons. 12 (3). $17-$ 24.

Prokazina, N.V. (2003). Studentship in the system of co-management: Development factors of social interactions in HEl: PhD dissertation. Orel. $197 \mathrm{p}$.

Sashkin, M. (1986). Participative management remains an ethical imperative. Organizational Dynamics. 14 (4). 62-75.

Sermsuk, Th. (2013). Expectation towards Cooperative Education Management of Rajamangala University of Technology Isan Thailand. Procedia - Social and Behavioral Sciences, 13th International Educational Technology Conference. Vol. 103, 374-378.

Slobodyanik, S.S. (2000). Turning management into... co-management. The Head oft he School. Vol.2, Electronic Archive.

Tamarskaya, N.V. (2003). Forming of managing culture oft he teacher in the process of continuous professional training: monograph. Kaliningrad: KSU. 160 p.

Tokareva, L.A. (2001). Co-management as the condition of modernisation of the system of modern education in Russia: PhD dissertation. Saratov. 159 p.

Utorov, O.R. (2008). Self-realization oft he teen in the conditions of co-management in additional education institution: PhD dissertation. Chelyabinsk. 186 p.

Yasvin, V.A. (2001). Educational Environment: from modelling to projecting. Moscow: Smysl. 365 p.

Yukl, G. (1971). Toward a behavioral theory of leadership. Organizational Behavior and Human Performance. 6 (4). $414-440$. 